\title{
Was Bosnian Queen Catherine a member of the Third Order of St. Francis?
}

\begin{abstract}
In Franciscan tradition and historiography Bosnian Queen Catherine $(\dagger 1478)$ has long been recognized as a blessed Franciscan tertiary. During her exile from her kingdom, which, after 1465, she spent in Rome, the queen turned to the Franciscan Order and the Church of St. Mary Aracoeli where she found her final resting place. The importance of the Franciscan Order during the Roman period of her life is shown by the fact that of the seven witnesses mentioned in the text of her testament as many as six belonged to the Franciscan monks of the Aracoeli monastery. This paper aims to present and examine available data on the queen's relations with the Franciscans and her membership in the Third Order of St. Francis, in order to try and offer a new insight into that aspect of her life and activities.
\end{abstract}

Bosnian Queen Catherine is certainly one of the most famous and best loved characters of medieval Bosnian history. ${ }^{1}$ A lot has been written about her life, mainly because of the sad way in which she lost her husband, Kingdom and children, in the space of only a couple of years, dying later alone as a stranger in a foreign land, but also because of the fact that later Franciscan tradition venerated the Queen as Blessed, considering her to have been a member of the Third Order of St. Francis. ${ }^{2}$

A cursory glance at the available sources shows that substantial contemporary evidence for this claim does not exist. Works created during Queen Catherine's lifetime do not explicitly state or mention that she was a Tertiary, and the authors who subsequently wrote about this topic usually based their conclusions on indirect information, of which the oldest can be dated to almost half a century after the Queen's death in Rome in 1478. Therefore, the aim of this contribution is to use the available documentary and narrative sources in an attempt to answer the

1 On the literature about Queen Catherine see: KURTOVIĆ 2005: 201-211. Of the most important biographical works it is worth to single out: KUKULJEVIĆ-SAKCINSKI 1825: 2-13; RUVARAC 1893: 467-477, 565-574; THALLÓCZY 1914: 110-120; DRAGANOVIĆ 1978; PANDŽIĆ 1979: 15-25; TOŠIĆ 1997: 73-112; REGAN 2010.

2 JELENIĆ 1912: 67, 212; DRAGANOVIĆ 1978: 47; SEMREN 1995: 114-122; RUNJE 1997: 68. 
question posed in the title of the article: was Bosnian Queen Catherine a member of the Third Order of St. Francis?

The question itself has never been previously asked in this way, and it can be assumed that this is down to the already mentioned lack of direct evidence which could be used to solve the dilemma. Since historians are regularly restricted by the quantity and quality of sources at their disposal, Catherine's modern biographers were content only to mention that she was a Tertiary, without discussing or elaborating the subject any further. This topic was not even considered in the published proceedings from the conference about Queen Catherine which was held in Sarajevo in 1978. Despite the fact that Alojzije Ištuk, who was then the Provincial Superior of the Franciscan Province of Bosnia Argentina, claimed in his opening speech that the Franciscans considered it their ,solemn duty“ to mark the $500^{\text {th }}$ anniversary of Queen Catherine's death ,but not because she was a Queen, but because she was a Tertiary“, and that the „fact that Catherine as a Tertiary belonged to the great Franciscan family" served as incentive for the celebration and organization of the symposium ${ }^{3}$, none of the authors devoted more attention to the issue of her membership in the Third Order.

Certain progress regarding the investigation of this subject was made in the last few decades, primarily due to the research published by Fr. Petar Runje ( $\dagger$ $2014)^{4}$, but also due to a book written by Lorenzo Tacchella $(\dagger 2008)$, the longserving ambassador of the Sovereign Order of Malta in Bosnia and Herzegovina. Even though the title of the book directly mentions Catherine's membership in the Third Order, the author did not examine the issue in detail, focusing mostly on the publishing of valuable documents from Italian archives. ${ }^{5}$

\section{$I$.}

The opinion that Queen Catherine was a Tertiary rests on a short text written about her by Fra Marian from Florence, a chronicler of the Franciscan Order. However, this book is lost today and we only know about its contents on the basis of a brief description which was published at a later date. Since Fra Marian died in 1523, his work must have been composed somewhat earlier than that year.

$3 \quad$ IŠTUK 1979: 10.

4 RUNJE 1986: 34-36; Isti 1987: 413-417; Isti 1997: 67-82; Isti 2001: 188-189, 201; Isti 2012: 181-184.

5 TACCHELLA 2002. I would like to use this opportunity to express my deepest gratitude to His Excellency Christof M. Fritzen, Ambassador of the Sovereign Order of Malta to the Republic of Austria and to Bosnia and Herzegovina, as well as to Dr. Valeria Maria Leonardi, archivist and librarian of the Sovereign Order of Malta, who helped me obtain the book. I am also especially indebted to Valérie Guillot, who was very supportive throughout. 
According to his note, Catherine lived as „devotissima Regina“ for many years under the Third Rule of Blessed Francis, wearing a habit in public. ${ }^{6}$

All the books which were created thenceforth can be divided into two groups - those which mention that the Queen entered the Order, and those which omit this information, focusing rather on other aspects of her life. For instance, the Portuguese Franciscan and Bishop of Porto, Marcos da Silva († 1591), whose work was originally published in Lisbon from 1557 to $1568^{7}$, and Spanish historian Pedro de Salazar y Mendoza $(\uparrow 1629)$ in a book printed in $1612^{8}$, both state that Queen Catherine took up the habit of the Third Order. On the other hand, there are a significant number of $16^{\text {th }}$ and $17^{\text {th }}$ century authors who wrote about her, but did not mention either the fact that she was a Tertiary, nor that she was honoured as blessed by the Franciscans. In his posthumously published work, the Italian humanist, historian and theologian Raffaele Maffei Volaterranus $(\dagger 1522)$, also writes about the Bosnian Queen, how the Turks expelled her from her Kingdom and that she died in Rome, but says nothing more than asserting erroneously that King Stephen [Thomas] was her brother. ${ }^{9}$ Another Italian historian, Marco Guazzo from Padua $(\dagger 1556)$, states in his book from 1553 that the Bosnian Queen was received in Rome by Pope Paul II, that he provided her with an honourable living, and that his successors continued this provision until her death, but makes no mention of the Queen's connections

6 „Anno Domini 1478, die 25 octobris, Rome, illustrissima Domina Catherina Bosne regina ex hac luce subtracta in Araceli sepellitur. Hec siquidem devotissima regina, pluribus annis sub 3 Regula beati Francisci vixit habitumque publice portavit“, DE FLORENTIA 1911: 326. See also PANDŽIĆ 1978: 21.

7 „L'anno 1478 à 25 d'Ottobre passò di questa vita le deuotissima Regina della Bosna, Donna Chaterina del Terz'ordine di S. Fran. che fu figliuola del Duca di Sauee, e di Helena del Sangue di Constantino Imperatore, moglie del Re di Bosna, dopò la cui morte essendosi impatronito il Turco del suo Regno. Questa diuota Regina si ridusse nel grembo della Chiesa Santa, e giunta à Roma fu benignamente dal Sommo Pontefice riceuuta, e nobilmente sostenata, venendo à morte volse esser sepolta in Araceli, \& ordinò il Papa ch'ella fusse posta auanti la grada dell' altar maggiore, e fece coprire la sepoltura con vna pietra di marmo, dou'è scolpita la sua imagine con la corona regale in capo." DA LISBONA 1591, Lib. VI: p. 209.

8 „Doña Catalina Reyna de Bosna, hija que fue del Duque de Sabee, y de Elena de linaje de Constantino Emperador, despues de muerto su marido los Turcos le tomaron el Reyno de Bosna, y ella se vino a Roma, a donde fue muy benignamente recebida, y honradamente sustentada. Y recinio el abito de la tercera Orden de san Francisco, y quando murio se mandó enterrar en la Iglesia de Araceli Conuento que es de san Francisco; y el Papa la mandó enterrar delante de las gradas del Altar mayor, y cubrir fu sepultura con vna hermosa piedra, en que está labrada su imagen con corona de Reyna. Fallecio año de 1478. a veynte y cinco de Otubre“. DE SALAZAR 1612: 415.

9 „Rex Stephanus (hoc enim nomine reges eorum uocant) a Ioanne Caruaialla S. Angeli Cardinale baptisma de more accepit. Is fuit germanus Bosnae reginae quae a Turcis expulsa, Romae nostra memoria Pontificum misericordia uictabat, \& extincta est.“ MAFFEI 1530, Lib. VIII: p. 93. 
with the Franciscans. ${ }^{10}$ Contrary to the claim of some of Catherine's modern biographers, Francesco (Annibale) Gonzaga, the erstwhile Bishop of Mantua, does not refer to her as a Tertiary in his seminal book De origine Seraphicae religionis Franciscanae eiusque progressibus published in 1587. ${ }^{11}$ Spanish Dominican scholar Don Alfonso Chacón († 1599), who published the wellknown reproduction of Catherine's tomb, likewise fails to mention that the Queen belonged to the Third Order of St. Francis. ${ }^{12}$ The Ragusan Benedictine chronicler Mauro Orbini wrote about the Queen in his famous book published in Pesaro in 1601, but he similarly makes no reference to her as a Tertiary. ${ }^{13}$ Some vague information about this matter can be found in the work of another Ragusan chronicler, Giacomo di Pietro Luccari, which appeared four years later, where he claims that the Queen, conceding the futility of her attempts to return her children from Turkish captivity, decided to give up on this World and become a nun. ${ }^{14}$

A veritable change in the portrayal of Queen Catherine in literature came after the publishing of the liturgical book Martyrologium Franciscanum in 1638, where she was mentioned not only as a Tertiary, but also for the first time as

10 „STEFANO RE DI BOSSINA. PRESO, e morto fu da Maometto Imperatore de Turchi Stefano Re di Bossina l'anno mille quatrocentosessantasei, non perdono questo Turco a sesso, ne ad eta alcuna, anchora che perdiuin uolere, e non altrimenti la Regina da tanta stragge se ne fuggi, $\&$ andata a Roma fu da Papa Paulo secondo proueduta del uiuere honoratamente, e da suoi successori continouata tal prouigione sin tanto ch'ella uisse. Bossina e una prouincia gia da gli atiquidetta Misia superiore, qual e tra la Dacia, e la Tracia, \& sono due Misie l'una superiore, e l'altra inferiore, \& l'una, \& l'altra presso il Danubio.“ GUAZZO 1553: 315.

11 GONZAGA 1587: 143. Cf. PANDŽIĆ 1978: 21.

12 „Post huius Reginae obitum, vt narrat Cardinalis Papiensis, duo ex eius familia obtulerunt Sixto Romano Pontifici testamentum, quo illa Regnum suum Ecclesiae Romanae legabat, addita conditione, si filius ex Turcis rediret, defectionis ante actae, \& Christianam fidem resumeret, in auita restitueretur. In signum autem legati Regni ensem dederunt, \& calcaria, quae Pontifex benigne accepta, prehendi sigillatim a quoque Cardinalium voluit, ipsumque testamentum, \& recepti Regni decretum in Archiuis Apostolicis condi imperauit." CIACCONIUS 1677: 41.

13 „Questa cosa vedendo Catharina, \& auueggendosi della fraude del Babaro, sdegnata si partì di Bosna, \& prima venne à Stagno, doue stette pochi dì, che se n' andò à Roma, \& iui finalmente morì. Fù sepelita nella Chiesa d'Araceli, doue (come si legge nella Chronica di Frati Minori) venendo questa Regina alla morte, vole esser se sepelita; $\&$ ordinò il Papa, che fù Sisto 4 . che fusse posta auanti la grada dell' altare maggiore, $\&$ fece coprire la sepoltura con vna pietra di marmo, doue e scolpita la sua imagine con vna corona regale in capo, \& con vn'Epitafio nella pietra, fatto in lingua latina, \& Slaua..." ORBINI 1601: 371.

14 „La Signoria, dopò hauergli fatto tutti quei honori, che maggiori per lei si poteuano, la fece menar con le galee in Ancona: oue fermata si non più che due dì, paßò à Roma, \& si condusse alla presenza del Papa, domandando da lui consiglio, \& aiuto: ma veggendo, che la sua causa era disperata, renunciate le cose del mondo, si fece Monaca; \& morendo fu sepelita in Araceli, con vn' epitafio di sopra la pietra del sepolcro." LVCCARI 1605: 108. 
Blessed. ${ }^{15}$ We can thus establish that this is the earliest known date when Queen Catherine began to be honoured within the Franciscan Order, and the majority of religious works written thereafter include the information that she was accepted into the Third Order. Therefore, this detail was then further reproduced by the $17^{\text {th }}$ century reformed Franciscan friar, preacher and theologian Girolamo Comboni, who even published two corresponding texts about the Bosnian Queen in two different parts his book Leggendario delle vite dei Santi, e Beati del Terz' Ordine del Serafico P. S. Francesco. Strangely, in one case she was named as Catherine ${ }^{16}$, and in the other she was identified as Constance. ${ }^{17}$ However, it is indicative that he did not include the Bosnian Queen, neither as Catherine, nor as Constance, among other saints and blesseds of the Third Order in a book which he published eight years previously. ${ }^{18}$ Nevertheless, the French theologian and Franciscan Tertiary Jean Marie [de Vernon] $(† 1670)$ mentioned the Queen as a

15 „B. Catharinae, Bosnae Reginae. f] Haec serenissima ac pientissima Regina, cum vidua esset, Regnumque Bosnae, vi \& armis Turca inuasisset: in Italiam descendit, Romamque veniens a Sixto IV. Summo Pont. benigne \& humanissime est recepta: cui \& pinguissimam annonam pro necessaria sui conditione assignauit. Patientiae autem et castitatis, atque pietatis fuit singularis: tanta vero fulsit humilitate, vt Tertij Ordinis insignia gestierit, \& moriens sepeliri voluerit in Conuentu Minorum Fratrum B. Mariae de Ara-coeli. Condita iacet in Ecclesa ante maius Altare, sub lapide marmoreo: iussu \& opera praefati Pontificis, ann. 1478. quo ipsa obierat“". MONASTERIO 1638: 491 (25. oct.)

16 „VITE DELLA B. CATERINA REGINA della Bosna, e del Beato Francesco Duca di Bertagna del Terz' Ordine del P. S. Francesco, estratte della Terza Parte delle Croniche nel Cap. 35. del sesto Lib. Cap. C.XXV. L'Anno 1478. a 21. d'Ottobre passo di questa vita la deuotissima Regina ella Bosna Donna Caterina del Terz Ordine di S. Francesco che fu figliuola del Duca di Sauec, e di Helena del sangue di Constantino Imperatore, moglie del Re di Bosna, doppo la cui morte essendosi impadronito il Turco del suo Regno. Questa deuota Regina si ridusse nel grembo della Chiesa santa, e gionta a Roma, fu benignamente dal Sommo Pontefice riceuuta, e nobilmente sostentata. Venendo à morte, volse esser sepolta in Araceli, Chiesa de' Frati Minori Osseruanti, \& ordinò il Papa, ch' ella fosse posta auanti la grada dell' Altar Maggiore, e fece coprire la sepoltura con vna pietra di marmo, dou'e scolpita la sua imagine, con la Corona Regale in capo.“ COMBONI 1648: 315.

17 „VITE DELLE BB. COSTANZA VEDOVA Regina della Bosna... estratte dalle Notationi d'esso Martirologio à car. $100 \&$ dalla Crologia del Gonzaga. Cap. C.C.XV. Qvesta Serenissima Costanza pijssima Regina, essendo restata vedoua, \& hauendo il Turco rouinato il Regno della Bosna, venne in Italia, \& andando à Roma, fù benignamente, \& cortesemente riceuuta da Sisto Quarto Sommo Pontefice, alla quale anco assignoò entrata per la sua sostentatione conforme alla conditione del suo stato, \& fù insigne di patienza, castità, e pietà, \& tanto risplendette nell' humiltà, che pigliò l'habito del Terz' Ordine di S. Francesco, \& morendo, volse essere sepolta nel Conuento de Frati Minori di S. Maria di Araceli in Roma, \& il suo corpo giace nella detta Chiesa auanto l'Altare Maggiore sotto vna pietra di marmo, bene ornata per ordine del sopradetto Pontefice l'anno 1458., nel quale essa morse. Di questa Beata Regina scriuono il Gonzaga nella prima parte sopra il Conuento d'Araceli, \& il' P. Luca Vadingo nel tom. 2. sopra l'anno 1251, citati nelle dette Notationi a car. 491.“COMBONI 1648: 463.

18 COMBONI 1640: 11. 
Tertiary in his „Perpetual Annals“ of the Third Order. ${ }^{19}$ The same was also recorded by another Italian reformed Franciscan friar Benedetto Mazzara ( $†$ 1692) in his Leggendario francescano ${ }^{20}$, as well as by the Austrian Franciscan author Vigilius Greiderer $(\dagger 1780)$ in his influential book Germania franciscana. ${ }^{21}$

19 „B. Catharina Bosniae Regina ... Professione Tertij Ordinis Franciscani obstricta omnes Regulas rigide observat, modestia praecellens, puritate, humilitate, patientia, necnon in divino cultu assiduirate incomparabili. Aegrotans graviter anno 1478. novit divinitus obitus sui proximitatem, cui se accinxit recipiendo Sacramenta, testamento cedens Ecclesiae quodcumque jus haberet ad possidendum Bosniae Regnum, atque declarans illud clientelarem ortum ducere a S. Petri Cathedra, ea tamen lege, ut si filius errorem agnosceret, ac fateretur, atque inter Christianos rediret, illi restitueretur majorum patrimonium ... Beata Catharina paulo post vitam cum morte commutavit 25. Octobris anno 1478. ut Soror Tertiaria Franciscana sepeliri peroptavit in Ecclesia Fratrum Minorum, Romae, quam communiter nominant de Ara Coeli ..." MARIA 1686: 478.

20 „Memorie della Serenissima Caterina Regina di Bosna del Tertio Ordine Francescano. La divotissima Regina della Bosna Donna Caterina Moglie di Tomaso Re di Bosna, Sorella di Stefano Duca di San Saba, figlia del Principe Stefano e di Elena del sangue di Constantino Imperadore, vedendo cotesta il gran frutto, che facevano i Frati Minori nell' anime del suo Regno gli si affezionò oltremodo, onde pregò con diverse lettere Papa Calisto Terzo conceder ad un Contrento, che avevano quelli nel suo Reame molte Indulgenze, e privilegi. Dopo la morte del Re suo marito, avendo il Turco occipato tutto il suo Stato, se ne venne in Roma in tempo di Papa Sisto Quarto, dal quale fu onorevolmente ricevuta, e sostenuta; diede singolari e sempi di pietà, pazienza, ed umiltà, conforme gli Autori registrano, attestando, che prese l'abito del Terz' Ordine del Padre San Francesco, e che poi sempre il portò, del che viene non poco commendata. Infermatasi a morte fece il suo testamento, e lo mandò al Papa, istituendo erede del sudetto Regno la Chiesa Romana, aggiontavi questa condizione, che se il figlio si separasse da' Turchi, si pentisse dell' errore commesso, e di nuovo professasse la Fede Cattolica, potesse rientrar in possesso del dominio, in segno di questa sua ultima volontà mandò la spada del Re, e li speroni al Pontefice, il quale ricevendo il tutto benignamente fece anco pigliarlo nelle mani di ciascheduno Cardinale in particolare, e poi comandò, che tale testamento, ed il decreto della ricevuta fosse posto nell' Archivio di Castello Sant' Angelo. Passata che fu poi essa Regina da questa a miglior vita, il medesimo Pontefice le celebrò solenni essequie. Il di lei corpo fu sepellito nella Chiesa de' Frati Minori in Araceli, in un'Avello fabricato a spese della medesima defonta davanti l' Altare Maggiore con un' onorevole Epitaffio rapportato dal nostro Annalista 1251. mumero 60. e 1478 num. 67“. MAZZARA 1722: 350.

21 „Acta Virtuosa Catharinae Reginae Bosnae tertii Ordinis S. Francisci Alumnae. Catharina, Filia Stephani Cosaciae Ducis de S. Saba, ex genere Helenae, \& domo Principis Stephani descendit. Thoro matura, Stephano Thomae Regi Bosnae nupsit, \& ex eodem tres liberos, Authoribus notos tulit, videlicet Stephanum, infelicem Patris in regimine Bosnensi Successorem, Sigismundum, Bosna a Turcis occupata, in spurcitias Mahometis abreptum, \& Catharinam, eodem veneno infectam. In statu matrimoniali varia specimina pietatis edidit. Labores spirituales, quos Fratres Conventus Jajcensis, S. Catharinae sacri, magna cum solertia subibant, eidem intensum affectum erga illos instillarunt, ac moverunt, ut a Calixto III. varias indulgentias, \& privilegia pro hoc Conventu an. 1458. petierit, \& obtinuerit. Viro suo modo incerto, uti indicatum n. 360., ex vivorum calculo amoto, Turcae Regnum Bosnae maxima ex parte occuparunt. Regina in Dalmatiam se recipiens, inde Romam petiit, ibique circa an. 1466. (evincit hoc testamentum ejus, moram Romanam ad 12. annos elevans) advenit, a Paulo II. honorifice excepta, ac ab eodem, \& Sixto IV. PP. Minorita Conventuali integerrima charitate nutrita. Hic se totam pietati, patientiae, \& humilitati, ac aliis virtutibus devovit; nec non habitum tertii Ordinis S. P. Francisci, de quo varii Authores Ordinis testimonium ferunt, devotissime suscepit, \& in eo per reliquos vitae dies 
The Spanish Franciscan chronicler, Eusebio González de Torres (fl. ca. 1725), also wrote in the same spirit ${ }^{22}$, and already by the $19^{\text {th }}$ century, Catherine was regularly thought of as a Tertiary in various works. Thus we can even encounter her name in the German edition of the Complete Rule Book for the Members of the Third Order of St. Francis, published in Munich in 1844, as ,pious Queen Catherine“, venerated on the $25^{\text {th }}$ of October, and described as „very patient in adversity“. ${ }^{23}$ Despite the fact that the process of Catherine's beatification was never officially initiated, and that she was considered as a Servant of God in an overview of Croatian saints from $1985^{24}$, she is still honoured by Bosnian Franciscans as blessed.

II.

As for Catherine's personal spirituality, it must be said that she grew up in a very heterogeneous religious environment. Her father, Duke Stephen Vukčić, was not always considered a Catholic, while her mother, Helena Balšić, was the granddaughter of an Orthodox Serbian saint - Prince Lazar, who was slain by the Ottomans at the battle of Kosovo in 1389. Consequently the issue of Catherine's religious upbringing remained open for a long time in historiography. However, despite the apparent lack of information for her early life there can be no doubt that sources about her relationship with the

incessit. Ultima aegritudine correpta, Papae suum misit Testamentum, quo Bosnae Regnum Romanae Ecclesiae transcripsit, addita conditione, ut si filius suus legitimus Sigismundus, a Turcis se separaturus, defectionem anteactam detestaturus, \& catholicae Fidei denuo nomen daturus sit, in avita restitueretur: secus, haec voluntas sit nulla, \& Catharina sua filia succedat, modo Sectam Mahometicam abjuratura sit. In signum hujus ultimae voluntatis ensem Regis, \& calcaria submisit: Pontifex autem, his benigne acceptis, jussit, ut sigillatim ab uno quoque Cardinalium prehendantur, ipsumque Testamentum, \& Sedis Apostolicae de eo recepto decretum, in Archivis molis Hadrianae reponantur. An. 1478. die 25. Octobris piissima Regina exspiravit, cui Pontifex inferias fecit, omnemque exhibuit honorem. Condita est in Ecclesia FF. Minorum ad Aram coeli, in qua ante altare majus Sepulchrum, Reginae sumptibus elaboratum, sub hac inscriptione Latina, \& Illyrica conspicitur: Inscriptio Sepulchralis. Perpensis his a veritatis tramite defecit Cl. Timon, mortem hujus Reginae in Hung. nova ad an. 1428. revocans, \& Thomae Regi Bosnae Mariti jura relate ad eam denegans." GREIDERER 1777: 221-222.

22 „De la Reyna de Bosna, Muger del Rey Thomas, dexo ya dicho en este Libro, que por su cordial devocion a nuestra Religion Serafica, vistio el Abito descubierto de la Tercera Orden, y quiso, que con ella enterrassen en nuestro Convento de Ara Coeli de Roma, a donde se vino desde sus Estados por la razon que alli insinue." GONZALES 1719: 575.

23 „Oktober 25. Die gottselige Katharina, Königin von Bosnien; sehr geduldig in Widerwärtigkeiten, 1478." Vollständiges Regel-Buch 1844: 113. However, Catherine cannot be found in the extensive „Calendar of the Canonised and Beatified Saints of the Order, arranged according to the Months in the Year", published in Father Emidius' Manual of the Third Order of St. Francis of Assisi. EMIDIUS 1869: 169-266.

24 JURIŠIĆ 1985: 173. 
Catholic Church, especially with Franciscans, become more frequent after her marriage to Bosnian King Stephen Thomas in $1446 .{ }^{25}$ In the following year, Pope Nicholas V granted her the permission to have two Franciscan monks in her retinue, having chosen them as her chaplains. ${ }^{26}$ On the same date the Pope conceded indulgences to all who visited the church of the Holy Trinity in Vrili on Kupres, which was built on the initiative of Queen Catherine. ${ }^{27}$ Much later, in December of 1458, Pope Pius II also conceded certain pardons to pilgrims who journeyed to the church of Saint Catherine in Jajce which was also established on the Queen's orders..$^{28}$ It ought to be pointed out that next to this church there was also a „domus" of the Friars Minor of the Bosnian Vicariate, which serves as further testimony of the strong connections between the Queen and the Franciscans in this period.

After the Ottoman conquest of Bosnia in 1463 Catherine first sought refuge in Dubrovnik and other coastal towns, before transferring to Rome a few years later. There she received a financial stipend from the Pope, which was taken from the funds

25 ĆOŠKOVIĆ 1988: 103-107.

26 „Charissimae in Christo filiae Catharinae reginae Bosnae illustri. Devotionis tuae sinceritas, quam ad Nos et Romanam geris ecclesiam, prout nuper etiam opere demonstrasti, dum te ad orthodoxae fidei unitatem sponte cum christifidelibus reduxisti, promeretur, ut petitionibus tuis, quas ex devotionis fervore prodire conspicimus, favorabiliter annuamus. Tuis itaque supplicationibus inclinati, devotioni tue, ut duos fratres ordinis minorum de observantia regulari ubicunque te illos in vicaria Bosne reperire contigerit, quos ad hoc duxeris eligendos, in tuos capellanos, quotiens opus fuerit, recipere illosque apud te tanquam tales in servitiis tuis ad celebrandum missas et alia divina officia tenere, nec non ad civitates, villas et loca quecunque, etiam Romanam Curiam, superiorum suorum dicti ordinis licentia non requisita, pro tuis et regni tui necessitatibus libere et licite ducere et transmittere possis, dictisque fratribus, ut servitiis tuis insistere aliaque singula premissa facere possint et valeant, tenore presentium indulgemus. Nulli ergo etc. nostre concessionis infringere etc. Si quis autem etc. Datum Rome apud Sanctum Petrum anno incarnationis dominice millesimo quadringentesimo quadragesimo septimo, quartodecimo Kal. Iulii. Pontificatus nostri Anno Primo" (18 ${ }^{\text {th }}$ of June 1447). HÜNTEMANN 1929: 539-540; THEINER 1860: 235.

27 „Nicolaus EPISCOPUS etc. ut supra. Licet is, de cuius etc. Cupientes igitur, ut ecclesia, quam in honorem sanctissime et individue Trinitatis pro sua devotione edificare cepit Carissima in Christo filia Caterina Regina Bosne in loco Verlau nullius diocesis in regno Bosne..." $\left(18^{\text {th }}\right.$ of June 1447). THEINER 1860: 234. Contrary to the thought of DRAGANOVIĆ 1978: 30, that Queen Catherine also ordered the construction the church of Saint Mary in Greben, the document which concedes indulgences to those pilgrims who visit the said church makes no mention of the Queen. See THEINER 1860: 234.

28 „Cum itaque dilecta in Christo filia Catherina Regina Regni Bosne, quod hereticis et scismaticis inquinatum est, magnum ad ecclesiam sancte Catherine in Castro Iayce dicti Regni, que domus fratrum ordinis minorum de observantia Vicaria dicti Regni existit, gerat devotionis affectum, ut Christo lucri faciat eiusque fideles in Christi fide sanctorumque devotione roboret, ac alios, qui extra sunt, ad fidem Christi quasi apes augmentosa augeat et deducat, summo cum desiderio nobis supplicari fecit, ut ecclesiam predictam celestis muneris largitione dotare dignaremur." THEINER 1860: 318. See also: KUJUNDŽIĆ 1972: 273-284. 
allocated for the crusade against the Ottomans. ${ }^{29}$ The Roman period of the Queen's life attracted many researchers, and therefore it is much better known. ${ }^{30}$ However, in all the sources created at that time we cannot find news that the Queen actually accepted the Rule of the Third Order and took the habit as one of the outward signs of its membership. In the two crucial places where we could expect such information to be found, these facts are obviously lacking. Namely, in her testament, created only a few days before her death, the Queen omits to mention, or in any way to imply, that she belonged to the Third Order. ${ }^{31}$ If she was a Tertiary, we could suppose that at least something in this testament would suggest that. On the other hand, the $9^{\text {th }}$ chapter of the rule of Pope Nicholas IV from 1289 stipulates that all those who are able to do so, must compose their last will in the course of three months after joining the Order so that they could „devote themselves to the duties of their holy vocation and the salvation of their souls “. ${ }^{32}$ Catherine's testament was written on the $20^{\text {th }}$ of October 1478, five days before her death. Does this mean that the Queen joined the Third Order only three months earlier? How can we reconcile this with the fact that Fra Marian mentions that she was a Tertiary ,pluribus annis“? Maybe the Queen composed her testament earlier, but chose to change it in the interest of the Holy See just before her death. We can speculate even further, but this will not bring us closer to a solution.

There are also no traces about the Queen's association with the Third Order on the inscription on her tombstone, not in the original Cyrillic, nor in the subsequent Latin version. ${ }^{33}$ The contemporary Roman authors, who wrote about Catherine's stay in Rome, do not mention her connections to the Franciscans, nor the fact that she took the vow of the Third Order. ${ }^{34}$ This could be explained by assuming

29 The sum was initially 100 gold ducats, and was paid from 1467. GOTTLOB 1889: 292. It was later periodically increased, until it settled at 200 ducats: „Latinus miseratione divina episcopus Tusculanus cardinalis de Ursinis, domini pape camerarius, spectabilibus viris Guillermo et Johanni de Pazzis et eorum sociis de reuerendissima curia pecuniarum s. cruciale depositariis salutem in Domino. De mandato sanctissimi domini nostri pape, nobis super hoc specialiter facto, et auctoritate nostri camerariatus officij vobis harum serie mandamus, ut de pecuniis s. cruciate penes vos existentibus solvatis et numeretis illustrissime domine Caterine regine Bosne seu eius legittimo nuncio pro ea recipienti florenos auri de camera papales ducentos pro eius consueta subventione et sustentatione presentis mensis septembris et octobris proxime futuri etc. " $\left(1^{\text {st }}\right.$ of September 1476). JELIĆ 1904: 167. The same expenses were paid each month until 1478. See also: PASTOR 1900: 194-195; THALLÓCZY 1914: 110; PANDŽIĆ 1978: 19; TOŠIĆ 1997: 94.

THALLÓCZY 1914: 110-120; TACCHELLA 2002: 79-130.

(20 $0^{\text {th }}$ of October 1478), THEINER 1863: 509-511.

32 EMIDIUS 1869: 56, 96-96.

33 ARNDT 1977: 211-223; MEKANOVIĆ 2014: 199-209.

34 For instance, both Cardinal Jacopo Ammanati-Piccolomini in his diaries (covering the period from 1472 to 1479), and Gaspare of Verona in his biography of Pope Paul II, fail to mention any details concerning the Queen's connections to the Franciscans even though they write extensively about her monthly income and testament. See CARUSI 1904: 143-144, 149 and ZIPPEL 1904: 60, 140. 
that Catherine, as a prominent political person, did not in fact live a true convent way of life, but that she only accepted the Tertiary rule, and therefore did not especially emphasize her membership in the Third Order. To contemporaries she was nonetheless more interesting as a queen of a far-away land who lived on the expense of the Holy See, so they might have not taken much notice of her spiritual activities.

Even though there is no firm contemporary evidence, this does not mean that something not recorded by contemporaries did not happen at all. Fra Marian clearly based his testimony about Queen Catherine on some kind of knowledge which was later lost. Looking at the available sources, we can observe that Catherine led a humble life of piety in Rome, attempting at all times to rescue her children from Ottoman captivity. She still maintained relations with Franciscans of which some were in her retinue. One of them, Fra Antonio Fermano, even performed diplomatic service for the Queen. ${ }^{35}$ Apart from that, in the new surroundings Catherine particularly grew closer to the Franciscan convent of Aracoeli on the Capitoline Hill, which served as an important centre of Tertiary activity at the time. According to her wishes, she was buried in this Franciscan church where her tombstone can be located even today. Members of the Third Order usually gathered around such Franciscan churches where they prayed, but where they also, in everyday contact with the Franciscans, developed a "new model of the devotional life" which later authors described as "lay echoes of mendicant spirituality“. ${ }^{36}$ The fact that Catherine was buried in that basilica is very important since many members of the Third Order found their resting places in Franciscan churches. In that sense, it is also important to note that of the seven witnesses named in Catherine's will, six were Franciscans from the Aracoeli convent. ${ }^{37}$

The Third Order was especially attractive to all those who wanted to develop a sense of community in the life of prayer and self-discipline. Among them there were many nobles and persons of royal blood who sought an escape from their rough surrounding in this way of life. Therefore, if she indeed were a Tertiary, Queen Catherine would belong to a long tradition of famous individuals who were buried in a Franciscan habit. Namely, the number of kings and queens who joined the Third Order since its inception is impressive, e.g. Ferdinand, King of

\footnotetext{
The Queen sent him to Macerata in 1475. COMPAGNONI 1783: 115.

36 ROBSON 2006: 166.

37 Apart from the 200 ducats needed to take care of the costs of her funeral, the Queen also bequeathed to the basilica of Santa Maria de Aracoeli her royal pallium made of brocade fabric and a multicoloured silk altar cloth which she used in her own chapel: „Item voluit et legavit dicte ecclesie sancte Marie de Araceli palium seu suum Regale mantellum de panno aurato. Item eidem ecclesie beate Marie de Araceli legavit et legat unum tusale sericeum pro altare cohoperiendo diversorum colorum, quod pro ornatu sue capello habebat." THEINER 1863: 510-511.
} 
Castile and Leon $(\dagger 1252)$, Hungarian Queen Elisabeth $(\dagger 1231)$, Queen Elisabeth of Portugal (†1336) as well as many others. ${ }^{38}$ We should also take into account the fact that the Third Order went through a revival in Italian towns of the $15^{\text {th }}$ century. St. John of Capistrano claimed in 1451 that there were 600.000 tertiaries in Italy at that time.${ }^{39}$ Despite the fact that it is impossible to confirm that number, it still remains impressive even if we reduce it significantly.

The spiritual climate of Queen Catherine's surroundings in Rome at the time was undoubtedly adequate for her admittance into the Third Order, and no sources speak directly against the fact that she truly might have been a Tertiary. In fact, it was probably through Franciscans that Catherine came into contact with the Society of the Blessed Virgin Mary which met up in the convent church and took care of the sick in the Roman hospital of St. Albert. ${ }^{40}$ Therefore, the Queen also engaged in charitable activities, and since charity and social work were basic principles of the Third Order ${ }^{41}$, this could be another indirect hint that would in a way corroborate the claim that Queen Catherine might well have been a Tertiary.

Finally, the Third Order of St. Francis was also active in Bosnia during the Middle Ages, and during the Queen's lifetime, so some authors thought that she might have joined it even before the Bosnian Kingdom collapsed under the military might of the Ottoman Empire..$^{42}$ Actually, available sources permit us to trace the long history of Tertiary activity in Bosnia back to the $14^{\text {th }}$ century. Since Bosnia was considered a missionary country at the time, members of both regular and secular Tertiary communities appear relatively early, and their presence is documented in the archives of Dalmatian towns. ${ }^{43}$ For instance, in 1369 in Split we encounter a mention of ,honourable man Fra Andreas of Bosnia, of the Third Order of Blessed Francis“. ${ }^{44}$ Two years later, on the $18^{\text {th }}$ of December 1372, a

38 MOORMAN 1968: 221-222.

39 HOFER 1955: 90.

40 In the name of gratitude to Queen Catherine, the members of this Society annually served holy mass for the Queen's soul for a long time after her death. PANDŽIĆ 1978: 22; TOŠIĆ 1997: 100 .

41 MOORMAN 1968: 426-427.

42 See PANDŽIĆ 1978: 21 and TOŠIĆ 1997: 99-100. DRAGANOVIĆ 1978: 38, was of the opinion that she became a Tertiary in Rome, whereas JELENIĆ 1912: 91-92, was much more flexible, leaving both options open.

43 ANČIĆ 1994: 119. However, these rare sources do not allow researchers to conclude anything more about their numbers and activities.

44 „Venerabilis uir frater Andreas de Bosna tertii ordinis beati Francisci ...“ (1 $17^{\text {th }}$ of August 1369), State Archives of Zadar, Splitski arhiv, busta 3, vol. 8/1, f. 17. Cf. ANČIĆ 1994: 119-120, n. 36; RUNJE 2012: 36. A few years before this, in 1367 and 1368 respectively, there are mentions in Split, of Tomaš Jakani from Usora and Marin from Cetina, who were both named as „fratincellus“, indicating that they were probably Tertiaries. ANČIĆ 1994: 119-120, n. 36. 
certain Fra Nicholas ,de penitentia“ brought a sealed letter of the Bosnian Vicar to Split and received the money which was bequeathed by the late Lady Catherine to Franciscans in Bosnia. Fra Nicholas was acting as a representative of the highest-ranking Catholic official in Bosnia and the epithet he was described with surely implies that he was a member of the Third Order of Penitents. ${ }^{45}$

These are not isolated cases. In April of 1413 Pope John XXIII allowed the Franciscan missionaries in Bosnia to receive and admit into the Third Order each individual should he so desire. ${ }^{46}$ Three decades later, in 1444, Pope Eugene IV placed the Tertiaries of the Bosnian Vicariate under the authority of the Bosnian Franciscan Vicar. ${ }^{47}$ Soon it was found out that there were many of them, and that they had built many monasteries, so the Pope issued another bull a year later allowing the Bosnian Vicar to legitimize and administer those establishments. ${ }^{48}$

There is one more known mention of a Bosnian Tertiary prior to the Ottoman conquest. In March of 1460 a certain Martin Radič ,,de Bosnia“ of the Third Order was ordained as a deacon on the island of Rab. ${ }^{49}$ However, we also have information about Tertiaries from Bosnia even after the fall of the Kingdom in 1463. Namely, fleeing their homeland due to the Ottoman danger and political instability, Bosnian Tertiaries became very influential in the neighbouring areas. Those who merit mention are the rich Bosnian nobleman Grgur Mrganić, who fixed churches and built houses for Tertiaries in Dalmatia, and Matej Mastilić (c. 1430 - 1525), known by his cognomen Bošnjak (i. e. the Bosnian), who was active in Zadar and elsewhere along the seacoast, establishing and building Tertiary monasteries with his own hands. ${ }^{50}$ After Pope Sixtus IV introduced a new status for the Third Order in 1473, Fra Matej was chosen as general minister of the Tertiaries in the Province of Dalmatia, and we know that he administered the Province in $1474 .{ }^{51}$

Around the same time another influential Tertiary from Bosnia lived and worked in Dalmatia. Namely, Stanica, the widow of Count Radić Radoslavić, a wealthy merchant from Jajce, spent the last years of her life in the female monastery,

\footnotetext{
$\overline{45}$ RUNJE 2001: 57-58.

46 Op. cit.: 106.

47 (31 $1^{\text {st }}$ of January 1444), FERMENDŽIN 1892: 184. The integral text of a later copy of the bull was published by ŠTEFANIĆ 1956: 264-266.

48 (31 $1^{\text {st }}$ of January 1445), THEINER 1860: 226; FERMENDŽIN 1892: 195-197.

49 „Fratrem Martinum qu. Radichi de Bosina Tertii ordinis S. Francisci in ordine dyaconatus“ $\left(11^{\text {th }}\right.$ of March 1460), RUNJE 1985: 114; Idem 2001: 118.

50 The cognomen is a much later addition. It was first used by Stjepan Ivančić ( $†$ 1925) at the end of the $19^{\text {th }}$ century. In most of the contemporary documents Matej Mastilić was styled as ,de Jadra“, meaning from Zadar, and only once in 1511 as „de Bosna“. See RUNJE 1985: 108, 113; Idem 1990: 147-158; Idem 2001: 118; ŠTEFANIĆ 1956: 207.

51 RUNJE 2001: 121.
} 
which she had established herself in her own house, adjacent to the Church of St. Cyprian in Split. In 1483, she completely devoted her life to God by entering the Third Order of St. Francis. ${ }^{52}$ Most of the information about her life stems from the last will that she produced a year later, leaving her vast estate with houses and possessions to the sisters of her monastery. She also left some of her belongings to the Church of St. Mary in Jajce, which she had founded around 1460, stating that those houses and properties ought to be governed by officials of the Bosnian Vicariate. ${ }^{53}$ Furthermore, Stanica maintained close connections with the Franciscan sisters in Rome. We know that Helen and Mary, who once served the late Bosnian Queen Catherine, asked the Holy See on the $15^{\text {th }}$ of January 1488 to give the house ,in Columne Urbis“ in Rome, in the vicinity of the Illyrian hospital of St. Jerome, to sister Stanica and her sisters Tertiaries. The house was in a bad state and desperately needed repairing. ${ }^{54}$

It is without a doubt that Stanica and Queen Catherine knew of each other, and there can likewise be no doubt that Tertiaries existed in Jajce, the erstwhile capital of the Bosnian Kingdom..$^{55}$ In her last will, written on the $11^{\text {th }}$ of January 1497 , Stanica stipulated that in the case that the monastery of sisters by the Church of St. Mary in Jajce should ever dissolve, her possessions should then be taken up by the ,reverend fathers of the Third Order of St. Francis, i. e. hermits“. She made the same provision for the monastery by the Church of St. Cyprian in Split. If there would be no more sisters in that establishment, then her estates would be sold and the obtained money used for buying a house for the nuns in Rome which are „of the Illyrian language, that is of the Dalmatian language". ${ }^{56}$ These are convincing indicators that a network of Tertiaries existed in the Jajce - Split - Rome triangle, and that Queen Catherine might well have been involved in its work.

\section{Conclusion}

Taking into account all the reliable and available evidence, we can see undisputable indications that Queen Catherine could have been a member of the Third Order of St. Francis. But these signs and clues offer us no detailed insight. The Queen's connections with the Franciscans, both before and after the Ottoman conquest of Bosnia, her humble and pious life in Rome, the unquestionable charity work she

\footnotetext{
52 For more on Stanica's life see: RUNJE 1986: 34-36; Idem 1987: 413-417; JURIŠIĆ 1992: 330337, 349-350; RUNJE 1997: 75; Idem 2001: 186.

53 RUNJE 1997: 76.

54 Op. cit.: 77-78; Idem 2001: 188.

55 Idem 1987: 417; Idem 2001: 118. About the Franciscan Third Order in Bosnia see also: DŽAMBO 1991: 175.

56 RUNJE 1997: 78; Idem 2012: 37, n. 22.
} 
did there, the possible ties she had with Tertiaries in Split and Jajce, all point us towards an affirmative assumption. However, the answer to the question posed in the title of this work must remain inconclusive since direct and contemporary evidence is still lacking. Therefore, keeping this question open, we may hope that its rightful answer might be found by the uncovering of new information in the numerous Italian archives which have only barely been investigated for the purpose of studying medieval Bosnian history.

\section{Bibliography}

ANČIĆ, Mladen. 1994. Pobožnost franjevaca Bosanske vikarije u drugoj polovici XIV. stoljeća. U Sedam stoljeća bosanskih franjevaca 1291.-1991., ur. Marko Karamatić, 109-125. Samobor: Franjevačka teologija Sarajevo.

ARNDT, Michael. 1977. Die ursprüngliche Grabinschrift der bosnischen Königin Katharina. Südost-Forschungen 36: 211-223.

CARUSI, Enrico (ed.). 1904. Il diario Romano di Jacopo Gherardi da Volterra [Rerum Italicarum Scriptores, Raccolta degli storici Italiani dal cinquecento al millecinquecento, XXIII/III]. Città di Castello: S. Lapi.

CIACCONIUS, Alphonsus. 1677. Vitae, et res gestae pontificum romanorum et S. R. E. Cardinalium ab initio nascentis ecclesiae usque ad Clementem IX. P. O. M. Alphonsi Ciaconii Ordinis Praedicatorum \& aliorum opera descriptae. Tomus III. Romae: Sumptibus Venantii Monaldini.

COMBONI, Girolamo. 1640. Regola del Terzo Ordine del Seraf. Padre San Francesco, con l'Espositione di essa, Breui, Decreti, \& Priuilegi Po[n]teficij, \& altre cose al detto Terzo Ordine spettanti. Bergamo: per Pietro Ventura.

COMBONI, Girolamo. 1648. Leggendario delle vite dei Santi, e Beati del Terz'Ordine del Serafico P. S. Francesco. Bergamo: per Marco Antonio Rossi.

COMPAGNONI, Pompeo. 1783. Memorie istorico-critiche della chiesa e de Vescovi di Osimo ... Opera postuma continuata e supplita con note e dissertazioni da Filippo Vecchietti. Tomo IV. Roma.

ĆOŠKOVIĆ, Pejo. 1988. Bosanska Kraljevina u prijelomnim godinama 1443-1446. Banja Luka: Institut za istoriju.

DA LISBONA, Marcos. 1591. Delle Croniche de Frati Minori del Serafico P. S. Francesco. Vol. III. Venetia: Appresso Barezzo Barezzi.

DE FLORENTIA, Marianus. 1911. Compendium chronicarum fratrum minorum. Archivum Franciscanum Historicum IV/2: 318-339.

DE SALAZAR, Pedro. 1612. Coronica y historia de la fundacion y progresso de la provincia de Castella de la Orden del Bienaventurado padre San Francesco. Madrid.

DRAGANOVIĆ, Krunoslav. 1978. Katarina Kosača bosanska kraljica. Prigodom 500 godišnjice njezine smrti (25. X. 1478.). Sarajevo: Vrelo života.

DŽAMBO, Jozo. 1991. Die Franziskaner in mittelalterlichen Bosnien. Werl-Westfalen: Butzon \& Bercker. 
Emir O. Filipović - Was Bosnian Queen Catherine a member of the Third Order of St. Francis?

EMIDIUS, Father. 1869. Manual of the Third Order of St. Francis of Assisi. London: Burns, Oates, and Company.

FERMENDŽIN, Eusebius. 1892. Actae Bosnae potissium ecclesiastica. Zagrabiae: Academia Scientiarum et Artium Slavorum Meridionalium.

GONZAGA, Francesco. 1587. De origine Seraphicae religionis Fra[n]ciscanae eiusque progressibus, de regularis observa[n]ciae institutione, forma administrationis ac legibus, admirabilique eius propagatione. Romae.

GONZALES, Eusebio. 1719. Chronica Seraphica. Vol. V. Madrid.

GOTTLOB, Adolf. 1889. Aus der Camera Apostolica des 15. Jahrhunderts. Innsbruck.

GREIDERER, Vigilius. 1777. Germania franciscana, seu chronicon geographo-historicum ordinis S. P. Francisci in Germania. Tomus I. Oeniponte [Innsbruck].

GUAZZO, Marco. 1553. Cronica di M. Marco Guazzo, ne la quale ordinatamente contiensi l'essere de gli huomini illustri antiqui e moderni, le cose e i fatti di eterna memoria degni occorsi dal principio del mondo sino a questi nostri tempi. Venetia.

HOFER, Giovanni. 1955. Giovanni da Capestrano - una vita spesa nella lotta per la riforma della Chiesa. L'Aquila.

HÜNTEMANN, Ulricus. 1929. Bullarium Franciscanum. Nova series, Tomus I (14311455). Quaracchi.

IŠTUK, Alojzije. 1979. Pozdravni govor pokrovitelja. U Povijesnoteološki simpozij u povodu 500 obljetnice smrti bosanske kraljice Katarine, gl. ur. Josip Turčinović, 10-11. Sarajevo: Kršćanska sadašnjost, Franjevačka teologija.

JELENIĆ, Julijan. 1912. Kultura i bosanski franjevci. Sv. I. Sarajevo: Prva hrvatska tiskara Kramarić i M. Raguz.

JELIĆ, Luka. 1904. Dvanaest isprava za povijest Hrvatske i susjednih zemalja od 1452.1535. g. Vjestnik Kr. Hrvatsko-Slavonsko-Dalmatinskog Zemaljskog Arkiva 6: 164-175.

JURIŠIĆ, Hrvatin Gabrijel. 1985. Naši domaći sveci. Prilog hrvatskoj hagiografiji. Bogoslovska smotra 55/1-2: 169-195.

JURIŠIĆ, Karlo. 1992. Samostan franjevačkih trećoredica „picokara“ Sv. Ciprijana u Splitu (1493.-1905.). Prilozi povijesti umjetnosti u Dalmaciji 33/1: 327-362.

KUJUNDŽIĆ, Juraj. 1972. Srednjovjekovne crkve u Jajcu. Dobri pastir 21-22: 273-284.

KUKULJEVIĆ-SAKCINSKI, Ivan. 1852. Katarina, kraljica bosanska. Neven I/1: 2-13.

KURTOVIĆ, Esad. 2005. Prilog bibliografiji radova o bosanskoj kraljici Katarini Kotromanić (1425-1478) (U povodu 580. obljetnice rođenja i 525. obljetnice smrti). Bosna Franciscana XXII: 201-211.

LVCCARI, Giacomo di Pietro. 1605. Copioso ristreto de gli Annali di Ravsa. Venetia.

MAFFEI, Raffaele. 1530. Commentariorum urbanorum Raphaelis Volaterrani octo et triginta libri, accuratius quam antehac excusi, cum duplici eorumdem indice secundum tomos collecto. Basilae.

MARIA, Joannes. 1686. Tertii Odinis S. Francisci Assisiatis Annales Perpetui. Paris.

MAZZARA, Benedetto. 1722. Leggendario francescano, overo istorie de Santi, Beati, Venerabili ed altri Uomini illustri, che fiorirono nelli tre Ordini istituiti dal serafico 
padre San Francesco raccolto e disposto secondo i giorni de mesi in quattro tomi. Tom. X. Venezia.

MEKANOVIĆ, Husein Sejko. 2014. Portret i nadgrobna ploča bosanske kraljice Katarine Kotromanić (1425-1478) u Rimu. Radovi Filozofskog fakulteta u Sarajevu (Historija, Historija umjetnosti, Arheologija) 17/3: 199-209.

MONASTERIO, Artur a. 1638. Martyrologium Franciscanum. Paris.

MOORMAN, John. 1968. A History of the Franciscan Order from Its Origins to the Year 1517. Oxford: University Press.

ORBINI, Mauro. 1601. Il regno de gli Slavi. Pesaro.

PANDŽIĆ, Bazilije. 1979. Katarina Vukčić Kosača (1424-1478). U Povijesnoteološki simpozij u povodu 500 obljetnice smrti bosanske kraljice Katarine, gl. ur. Josip Turčinović, 15-25. Sarajevo: Kršćanska sadašnjost, Franjevačka teologija Sarajevo.

PASTOR, Ludwig. 1900. The History of the Popes, from the Close of the Middle Ages. Vol. IV. London: Routledge \& Kegan Paul, St. Louis - Herder.

REGAN, Krešimir. 2010. Bosanska kraljica Katarina - Pola stoljeća Bosne (1425-1478). Zagreb: Naklada Breza.

ROBSON, Michael. 2006. The Franciscans in the Middle Ages. Woodbridge: Boydell \& Brewer.

RUNJE, Petar. 1985. Novi prilozi za život o. Mateja Bošnjaka-Mastilića, franjevca trećoreca (o. 1430-1525). Croatica Christiana Periodica IX/16: 107-118.

RUNJE, Petar. 1986. Trećoreci na području Jajca u srednjem vijeku. Vjesnik franjevaca trećoredaca 23/1: 34-36.

RUNJE, Petar. 1987. O crkvi svete Marije u Jajcu, trećorecima i časnoj sestri Stanici trećeg reda Sv. Franje u srednjem vijeku. Marulić 20/4: 413-417.

RUNJE, Petar. 1990. Prema izvorima [Novaja i vethaja 2]. Zagreb: Provincijalat franjevaca trećoredaca.

RUNJE, Petar. 1997. Tri hrvatske plemkinje franjevačke trećoredice. Kačić XXIX: 67-82.

RUNJE, Petar. 2001. Pokornički pokret i franjevci trećoredci glagoljaši (XIII-XVI st.). Zagreb: Provincijalat franjevaca trećoredaca, Kršćanska sadašnjost.

RUNJE, Petar. 2012. Prema izvorima II. Rasprave i članci o hrvatskim franjevcima trećoredcima glagoljašima. Uredio Tomislav Galović [Novaja i vethaja 9, Krčki zbornik 68, Posebno izdanje 61]. Krk-Zagreb: Povijesno društvo otoka Krka, Provincijalat franjevaca trećoredaca.

RUVARAC, Ilarion. 1893. Dvije bosanske kraljice. Glasnik Zemaljskog muzeja V: 467477, 565-574.

SEMREN, Marko. 1995. Mučenici i svjedoci vjere: iz srednjovjekovne povijesti Katoličke crkve u Bosni. Bosna franciscana III: 114-122.

ŠTEFANIĆ, Vjekoslav. 1956. Glagoljaši u Kopru g. 1467-1806. Starine JAZU 46: 203-329.

TACCHELLA, Lorenzo. 2002. Caterina regina di Bosnia, terziaria francescana e donata dell'ordine gerosolimitano di S. Giovanni di Rodi, poi di Malta (1424-1478): il cattolicesimo in Bosnia nei secoli 14.-15. Sarajevo-Milano: Arcivescovo di Vrhbosna. 
Emir O. Filipović - Was Bosnian Queen Catherine a member of the Third Order of St. Francis?

THALLÓCZY, Lajos. 1914. Königin Katharina von Bosnien. U Studien zur Geschichte Bosniens und Serbiens im Mittelalter, 110-120. München-Leipzig: Duncker \& Humblot.

THEINER, Augustin. 1860. Vetera Monumenta Historica Hungariam Sacram Illustrantia. Tomus II. Roma.

THEINER, Augustin. 1863. Vetera Monumenta Slavorum Meridionalium. Tomus I. Roma. TOŠIĆ, Đuro. 1997. Bosanska kraljica Katarina (1425-1478). Zbornik za istoriju Bosne i Hercegovine II: 73-112.

Vollständiges Regel-Buch für die Mitglieder des dritten Ordens des heiligen Franziskus von Assisi. 1844. München.

ZIPPEL, Giuseppe (ed.). 1904. Le Vite di Paolo II di Gaspare da Verona e Michele Canensi [Rerum Italicarum Scriptores, Raccolta degli storici Italiani dal cinquecento al millecinquecento, III/XVI]. Città di Castello: S. Lapi.

\section{Je li bosanska kraljica Katarina bila franjevačka trećoredica?}

Kraljica Katarina možda je najpoznatiji i najomiljeniji lik srednjovjekovne bosanske historije. O njoj se već mnogo pisalo, uglavnom zbog njezine životne sudbine i poznate priče kako je izgubila supruga, kraljevstvo i djecu te umrla u tuđini, ali također i upravo zbog toga što je u kasnijoj franjevačkoj tradiciji smatrana trećoredicom. Letimičnim pogledom na suvremene izvore primjećuje se da čvrsti podaci za tu tvrdnju izostaju te da su autori koji su pisali o toj temi svoje zaključke uglavnom temeljili na posrednim vijestima, od kojih se najstarija datira tek pola stoljeća nakon kraljičine smrti.

Mišljenje da je kraljica Katarina bila trećoredica zapravo se temelji na zapisu, koji je o njoj ostavio fra Marijan iz Firenze, u danas izgubljenom djelu koje poznajemo samo po kasnije objavljenom kratkom sadržaju. Budući da je fra Marijan preminuo 1523., njegovo je djelo moralo nastati malo prije tog datuma. Prema njegovoj zabilješci, Katarina je kao „devotissima Regina“ mnogo godina živjela pod trećom regulom blaženog Franje, noseći habit u javnosti. Sva djela nastala tijekom idućeg stoljeća možemo svrstati u dvije kategorije: knjige koje kraljicu spominju kao trećoredicu i one koje tu informaciju izostavljaju, fokusirajući se na neke druge aspekte njezina života. Njihov je omjer otprilike podjednak.

Iako sigurni suvremeni podaci o Katarininu članstvu u Trećem redu ne postoje, to ne znači da se ono što suvremenici nisu zabilježili nije nikada ni dogodilo. Fra Marijan je očito svoju izjavu morao temeljiti na nekom saznanju koje se u međuvremenu izgubilo. Promatrajući dostupne izvore, primjećuje se da je Katarina u Rimu vodila povučen i skroman život, prije svega okrenut vjeri i nastojanjima za vraćanjem djece iz osmanskog zarobljeništva. Ona je i dalje nastavila održavati veze s franjevcima, od kojih su se neki nalazili i u njezinoj pratnji. Zabilježeno 
je da je jedan od njih za kraljicu čak obavljao i poslaničku misiju. Osim toga, Katarina se u novoj sredini posebno približila franjevačkom samostanu Aracoeli, koji je u to vrijeme slovio kao značajan centar trećoredske djelatnosti. Prema osobnoj želji, kraljica je ukopana upravo u toj franjevačkoj crkvi, gdje se i danas nalazi njezina nadgrobna ploča.

Štoviše, potrebno je naglasiti da nijedan izvor nije u suprotnosti s mogućnošću da je kraljica Katarina uistinu mogla biti primljena u franjevački Treći red. To, između ostalog, pokazuju činjenice da je ukopana u franjevačkoj crkvi Aracoeli, da su mnoge ličnosti kraljevske krvi odabrale svoj život okončati kao trećoreci, da je upravo za Katarinina života trećoredska djelatnost u Italiji proživljavala procvat te da je posebno zabilježen kraljičin karitativan rad, koji se smatra jednim od temelja Trećeg reda. Međutim, ostavljajući postavljeno pitanje otvorenim, možemo se nadati da ćemo njegov odgovor moći dobiti tek pronalaskom novih podataka u brojnim talijanskim arhivima, koji su veoma malo iskorišteni za proučavanje srednjovjekovne bosanske prošlosti.

Ključne riječi: kraljica Katarina, Bosna, sv. Franjo, Treći red, Rim

Keywords: Bosnian Queen Catherine, Bosna, St. Francis, Third Order of St. Francis, Rome

Emir O. Filipović

Filozofski fakultet Univerziteta u Sarajevu

BiH-71 000 Sarajevo, Franje Račkog 1 emirofilipovic@gmail.com 


\section{FILOZOFSKI FAKULTET SVEUČILIŠTA U ZAGREBU \\ ZAVOD ZA HRVATSKU POVIJEST \\ INSTITUTE OF CROATIAN HISTORY \\ INSTITUT FÜR KROATISCHE GESCHICHTE}
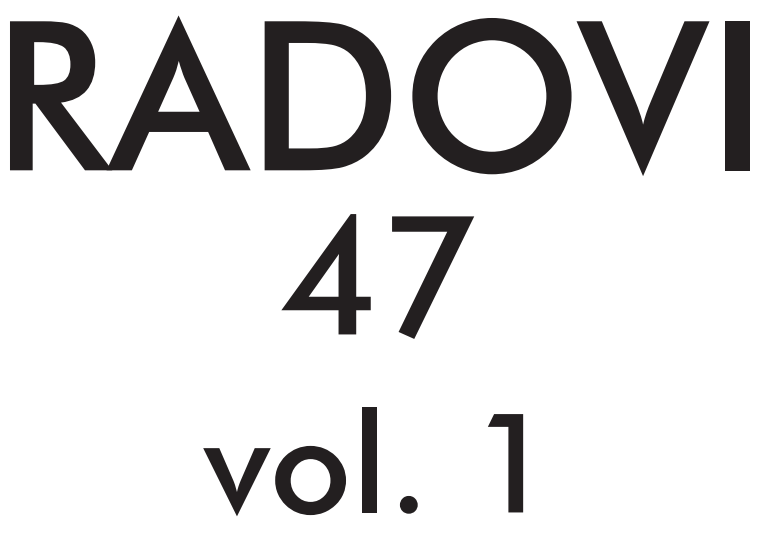

ZAVOD ZA HRVATSKU POVIJEST

FILOZOFSKOGA FAKULTETA SVEUČILIŠTA U ZAGREBU

\section{PF press \\ ZAGREB 2015.}




\title{
RADOVI ZAVODA ZA HRVATSKU POVIJEST FILOZOFSKOGA FAKULTETA SVEUČILIŠTA U ZAGREBU
}

\author{
Knjiga 47, vol. 1
}

\author{
Izdavač / Publisher \\ Zavod za hrvatsku povijest \\ Filozofskoga fakulteta Sveučilišta u Zagrebu \\ FF-press \\ Za izdavača / For Publisher \\ Vlatko Previšić \\ Glavni urednik / Editor-in-Chief \\ Hrvoje Gračanin \\ Izvršna urednica / Executive Editor \\ Inga Vilogorac Brčić \\ Uredništvo / Editorial Board
}

Bruna Kuntić-Makvić (stara povijest/ancient history), Zrinka Nikolić Jakus (srednji vijek/ medieval history), Hrvoje Petrić (rani novi vijek/early modern history), Željko Holjevac (moderna povijest/modern history), Tvrtko Jakovina (suvremena povijest/contemporary history),

Silvija Pisk (mikrohistorija i zavičajna povijest/microhistory and local history),

Zrinka Blažević (teorija i metodologija povijesti/theory and methodology of history)

Međunarodno uredničko vijeće / International Editorial Council

Denis Alimov (Sankt Peterburg), Živko Andrijašević (Nikšić), Csaba Békés (Budapest), Rajko Bratož (Ljubljana), Snježana Buzov (Columbus, Ohio), Svetlozar Eldarov (Sofija), Toni Filiposki (Skopje), Aleksandar Fotić (Beograd), Vladan Gavrilović (Novi Sad), Alojz Ivanišević (Wien),

Egidio Ivetić (Padova), Husnija Kamberović (Sarajevo), Karl Kaser (Graz),

Irina Ognyanova (Sofija), Géza Pálffy (Budapest), Ioan-Aurel Pop (Cluj),

Nade Proeva (Skopje), Alexios Savvides (Kalamata), Vlada Stanković (Beograd), Ludwig Steindorff (Kiel), Peter Štih (Ljubljana)

Izvršna urednica za tuzemnu i inozemnu razmjenu / Executive Editor for Publications Exchange Kristina Milković

Tajnik uredništva / Editorial Board Assistant

Dejan Zadro

Adresa uredništva/Editorial Board address

Zavod za hrvatsku povijest, Filozofski fakultet Zagreb, Ivana Lučića 3, HR-10 000, Zagreb

Tel. ++385 (0)1 6120 150, 6120 158, faks ++385 (0)1 6156879

Časopis izlazi jedanput godišnje / The Journal is published once a year

Časopis je u digitalnom obliku dostupan na / The Journal in digital form is accessible at Portal znanstvenih časopisa Republike Hrvatske „Hrčak“ http://hrcak.srce.hr/radovi-zhp

Financijska potpora za tisak časopisa / The Journal is published with the support by

Ministarstvo znanosti, obrazovanja i športa Republike Hrvatske

Časopis je indeksiran u sljedećim bazama / The Journal is indexed in the following databases:

Directory of Open Access Journals, EBSCO, SCOPUS, ERIH PLUS 
Naslovna stranica

Iva Mandić

Grafičko oblikovanje i računalni slog

Marko Maraković

Lektura

Samanta Paronić

Tisak

Web2tisak, Zagreb

Naklada

250 primjeraka

Časopis je u digitalnom obliku dostupan na Portalu znanstvenih časopisa Republike Hrvatske ,Hrčak“ http://hrcak.srce.hr/radovi-zhp

The Journal is accessible in digital form at the Hrcak - Portal of scientific journals of Croatia http://hrcak.srce.hr/radovi-zhp 


\section{RADOVI 47}

\section{vol. 1}

ZaVoda za hrVAtSku poviJest FILOZOFskoga fakulteta SVeuČILIŠTA u Zagrebu 


\title{
Tematski blok / Themed issue
}

\section{TREĆOREDSKA GLAGOLJAŠKA TRADICIJA U EUROPSKOM KONTEKSTU TERTIARY GLAGOLITIC TRADITION IN EUROPEAN CONTEXT}

\author{
Radovi međunarodnoga znanstvenog skupa \\ održanoga 27. i 28. IX. 2013. na Hrvatskom katoličkom sveučilištu u Zagrebu \\ u organizaciji \\ Provincije franjevaca trećoredaca glagoljaša u Zagrebu, Hrvatskoga katoličkog \\ sveučilišta u Zagrebu, Filozofskoga fakulteta Sveučilišta u Zagrebu - Odsjek za \\ povijest, Filozofskoga fakulteta Sveučilišta u Splitu - Odsjek za povijest, Instituta \\ za povijest umjetnosti u Zagrebu i Staroslavenskoga instituta u Zagrebu \\ Proceedings of the International Scientific Conference \\ held on 27th and 28th September 2013 at the Catholic University of Croatia in Zagreb \\ and organized by \\ the Province of the Glagolitic Friars of the Third Order Regular, Catholic University \\ of Croatia in Zagreb, Faculty of Humanities and Social Sciences of the University \\ of Zagreb - Department of History, Faculty of Humanities and Social Sciences of \\ the University of Split - Department of History, Institute of Art History, \\ and Old Church Slavonic Institute
}

Gosti urednici / Guest editors

\author{
Ivan BOTICA \\ Tomislav GALOVIĆ \\ Kristijan KUHAR
}

